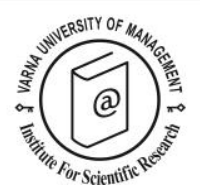

\title{
Climate change in low mountain ranges: Opportunities in sustainable Black Forest tourism
}

\author{
Tatjana Thimm ${ }^{1 *}$, Christine Bild ${ }^{2}$ and Michael Kalff ${ }^{3}$
}

Received: 30/06/2019 Accepted: 09/03/2019

\begin{abstract}
${ }^{1}$ Professor for Tourism Management at the Department of Business, Cultural and Legal Studies at Hochschule Konstanz, University of Applied Sciences, Germany; Alfred-Wachtel-Str. 8, 78462 Konstanz, Germany, Phone +49 7531 206-145. E-mail: Tatjana.Thimm@htwg-konstanz.de

${ }^{2}$ Graduate Geographer, Junior Researcher in the Department of Business, Cultural and Legal Studies at Hochschule Konstanz, University of Applied Sciences

${ }^{3} \mathrm{PhD}$ in Education for Sustainable Development, researcher in the Department of Business, Cultural and Legal Studies at Hochschule Konstanz, University of Applied Sciences

* Corresponding author
\end{abstract}

Coordinating editors: Andreas Kagermeier and Werner Gronau

\section{Abstract}

The aim of this paper is to portray the risks of climate change for low mountain range tourism and to develop sustainable business models as adaption strategy. A mixed-method-approach is applied combining secondary analysis, a quantitative survey, and qualitative in-depth-interviews in a transdisciplinary setting. Results show, that until now, climate change impacts on the snow situation in the Black Forest - at least above $1,000 \mathrm{~m}$ - have been mild and compensated by artificial snowmaking, and up to now have not had measurable effects on tourism demand. In general, the Black Forest appears to be an attractive destination for more reasons than just snow. The climate issue seems to be regarded as a rather incidental occurrence with little importance to current business decisions. However, the authors present adaption strategies as alternatives for snow tourism, e. g. the implementation of hiking hostels, since climate change will make winter tourism in the Black Forest impossible in the long run.

Keywords: sustainable tourism, climate change, winter tourism

Citation: Thimm, T., C. Bild and M. Kalff (2019) Climate change in low mountain ranges: Opportunities in sustainable Black Forest tourism. European Journal of Tourism Research 23, pp. 63-70

\section{Introduction and Literature Review}

Climate change and all its consequences affect the various tourism branches in different ways (Elsasser et al., 2000), especially nature-based tourism is very vulnerable in this regard. The heavily touristed Black Forest, a low mountain range in South-West Germany, is expected to be confronted with the effects of climate

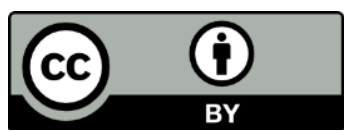

RESEARCH PAPER
This work is licensed under the Creative Commons Attribution 4.0 International (CC BY 4.0). To view a copy of this license, visit https://creativecommons.org/licenses/by/4.0/ 
change, too. Especially winter tourism in the Northern and Southern Black Forest areas will face higher temperatures, more rainfall and hence less snow during the winter season (Roth et al., 2013).

However, according to Matzarakis \& Lohmann (2017), there will be no dramatic effects of climate change in low mountain ranges in Europe for the next three decades. The effects will become more significant from the second half of this century (ibid.). According to UM (Ministerium für Umwelt, Klima und Energiewirtschaft Baden-Württemberg, 2017) winter sport will be impossible in low mountain ranges by the end of the $21^{\text {st }}$ century. To face climate change, adaption strategies must be implemented (Abegg \& Elsasser, 1996; Elsasser et al., 2000).

In the context of tourism and climate change, both, the demand and supply sides are of interest. According to Gössling et al. (2012) the tourist has a fast adaptive capacity and therefore is causing shifts in demands quickly according to his perception and reaction towards climate change.

Climate change in South-West Germany (i. e. the state of Baden-Württemberg), as well as connected subjects such as the long-term behaviour of snow covers, has been analysed by various studies, including: Gebhard \& Höpker, (2015); Hemberger \& Utz, (2013); KLIWA (2005); UM (2017). Concerning the effects of climate change on summer tourism, it is assumed that the interest in holidaying in Germany is going to increase, since German summers become warmer (RADOST, 2012). Regarding winter tourism, it is expected that Alpine winter sports will no longer be possible in the low mountain ranges by the end of the $21^{\text {st }}$ century. Therefore, the development of year-round offers independent of snow is recommended to adjust to climate change (UM, 2017).

Abegg \& Elsasser (1996) and Elsasser et al. (2000) distinguish between adaptation and mitigation strategies with regard to the approach to tourism to be taken. According to Abegg \& Elsasser (1996), the adaptation strategies prevail, although mitigation strategies are important too. Roth et al. (2013) also see an increased need to act for the Northern and Southern Black Forest, due to the fact that winters will have less snow, also recommending the (further) development of winter sport alternatives. This is also reflected in studies that explicitly deal with the subject of winter tourism in the Black Forest or climate change in the Black Forest include Hodeck \& Hoveman, 2017, Endler \& Matzarakis, 2011, Schneider et al., 2009 and Koesler, 2011. In assessing the scope of consequences of climate change for Baden-Württemberg, LUBW (2013) compared and evaluated climate projections. In spite of the uncertainty involved in climate projections, there has been, and probably will continue to be, a long-term increase in the annual average temperature and a clear reduction in the annual frost days. Less rainfall in the hydrological winter half year and increased rainfall in summer are expected as well (LUBW, 2013).

Regarding the demand side, there are some studies that deal with the reactions of tourism demand to climate change (Gössling et al., 2012). The ecological footprint of the tourism sector has been subject to intense scrutiny (Gössling, 2002 and Gössling et al., 2005) and the variables of tourism and climate change have been scientifically analysed as well (e.g. Pröbstl-Haider et al., 2015). Yet, there has not been any detailed analysis that deals with adaptation or mitigation strategies of the Black Forest tourism industry regarding climate change, or the examination of changes to tourist demand in the Black Forest in the scope of climate change.

To fill this research gap the following research questions can be derived:

- To what extent does climate change affect the Black Forest as a tourist destination?

- How does the tourism industry in the Black Forrest adapt to climate change so far?

- How important is snow for winter tourism and recreational purposes in the Black Forest?

- What kind of sustainable post-snow era tourism activities are possible?

\section{Methodology}

To systematically investigate these research questions a mixed-methods-approach including 
a quantitative survey, in-depth-interviews, offer analysis, secondary analysis and webpage analysis was applied.

A focus was put on the analysis of the demand side and the importance of snow for winter tourism and recreational purposes in the Black Forest, forming the main part of the empirical analysis by conducting a quantitative survey (Jacob et al., 2013; Kruse, 2014). The topic of the survey was 'Holiday and leisure behaviour in the region Hochschwarzwald (Upper Black Forrest) during winter' and it was conducted in cooperation with a Black Forest Tourism Organisation, a Black Forest hotel operator and an undergraduate student from another university of applied sciences. For the face-toface interviews a standardised questionnaire was used and this was based on another questionnaire developed by the undergraduate student for the written part of the survey. The questionnaire contained 23 questions in total and was divided into four parts asking questions about the kind of stay, about winter holidays in general, about the current winter holiday in the Black Forest, or in the case of locals, about their recreational behaviour in the current winter at the Black Forest, and finally about some personal information (e.g. age, gender, origin).

The interviews were held by students of the authors' university and the undergraduate student herself on three weekends in January and March 2018 (January $5^{\text {th }}-7^{\text {th }}, 13^{\text {th }} / 14^{\text {th }}$ and March $17^{\text {th }} / 18^{\text {th }}$ ) at five different locations in the Region 'Hochschwarzwald' in the southern part of the Black Forest, namely in Titisee, Feldberg, Hinterzarten, Todtnau and Schluchsee. The respondents were randomly chosen and of the 276 contacted people, 200 participated in the survey.

The survey focused on the differences between locals and guests, and between respondents participating in winter sport activities and those who do not. Since this study is an exploratory one, only a descriptive statistical analysis was conducted. The sample size does not qualify for a representative sample, but the tendencies of the results are quite obvious and allow certain conclusions.
Finally, after analysing the climate and tourism situation and the demand side, the offer side was examined in order to develop alternatives for the post-snow era. The offer analysis presents business models, services offered, and pricing of 22 hostels in low mountain areas in France, Germany, Switzerland and Belgium by interviewing the operators and/or examining data from their webpages. The in-depth interview participants formed a deliberate sample, since they all form part of the accommodation type of gîte d'etape, al low budget hostel, especially for hikers, and popular in French speaking regions of Europe. The purpose of this offer analysis was to examine its transferability to the Black Forest.

\section{Results}

Climate change and tourism in the Black Forest Regarding climatic trends, the following has been observed: shorter snow periods during the winter season, particularly around Christmas, as well as a shift of colder periods with steady snow cover towards the end of the winter. However, snow-related effects of climate change are more acute in lower regions, while areas above $1,000 \mathrm{~m}$ above sea level thus far appear to be less affected. Yearly weather changes are predominant over climate change effects for snow situations (LUBW, 2017; UM \& LUBW, 2016). Until now, climate change impacts on the snow situation in the Black Forest (at least above $1,000 \mathrm{~m}$ ) have been mild and compensated for by artificial snowmaking, so far without measurable effects on tourist demand. Winter tourism in the Black Forest is increasing $(+7.7 \%$ overnight stays 2011-2016) even more than summer tourism (+4.7\% overnight stays $2011-2016)$. This might be a spill-over effect of an overall increase in German tourism (mainly accounting for cities and coasts) which also increases disproportionately in winter $(+13.3 \%$ vs. $+9.3 \%$ overnight stays in 2011-2016, all statistics from the Statistisches Bundesamt 2011-2017), or a sign of good tourism management.

Despite decreasing snow-making potential due to rising temperatures, tourism stakeholders in winter tourism depend more and more on artificial snow. This results in an increased demand for energy and resources, thus further damaging sensitive ecosystems in low 
mountain ranges (Roth et al., 2005; Abegg, 2012). Contrary to climate projections regarding worsening snow conditions, huge investments in winter-related infrastructure such as ski slopes and lifts have been made in the recent past (Doering \& Hamberger, 2015). Businesses seem to view the climate issue as rather incidental, having little impact on their current business decisions. However, there are several mitigating developments showing environmental sensitivity in the Back Forrest. For example, tourists are encouraged to use public transportation by being offered a corresponding regional ticket that is included in the price of two overnight stays, thus reducing each visitor's carbon footprint (Schwarzwald Tourismus $\mathrm{GmbH}$, n. y.). The percentage of hotels that have implemented environmental management policies is unusually high in the Black Forest (UGA, 2017), although the numbers in total are still quite low.

\section{Analysis of tourism demand in the face of climate change}

The analysis of the importance of snow for tourists and for recreational purposes should show, as mentioned above, whether there are differences between locals and guests and between respondents who take part in winter sport activities and those who do not.

The 200 respondents include 175 (87.5\%) guests and $25(12.5 \%)$ locals. The participants who are residents of one of the following 16 communities (Breitnau, Eisenbach, Feldberg, Friedenweiler, Hinterzarten, Lenzkirch, Löffingen, Rothauser Land, Schluchsee, St. Märgen, St. Peter, Titisee-Neustadt, Todtmoos, Bergwelt Todtnau, Häusern and St. Blasien) are considered locals of the Hochschwarzwald. The participants who do not come from the Hochschwarzwald are mainly from other parts of the Black Forest (26.5\%), BadenWürttemberg (22.5\%) or other German regions (22.5\%). 52\% of the 175 guests are visitors on day trips; $48 \%$ are overnight guests. Nearly half of all respondents ( $n=199$, about 49\%) participate in winter sport activities during their stays (guests, $n=174$ ), or during the winter season 2017/18 (locals, $n=25$ ). Amongst the locals, $36 \%$ participate in winter sport activities. The winter sport activities mentioned most $(n=96)$ are skiing (about 49\%), snowboarding (about 16\%), sledding (about 14\%) and crosscountry skiing (about 12\%).

Given the first research aim of the survey, namely to analyse the importance of snow for winter tourism in the Hochschwarzwald, one question asked respondents to evaluate the importance of snow for their current stay (guests), or the importance of snow for leisure purposes during the winter season 2017/18 (locals)

The analysis of this question demonstrates that the presence of snow is very important for the majority of all respondents $(n=199)(53.77 \%)$. However, over $20 \%$ stated that it is not important at all. Snow seems to be more important for guests $(n=175)$ than for locals $(n=24)$ given that only $25 \%$ of the locals evaluated snow as very important, while nearly $58 \%$ of the guests did (see figure 1 )

Furthermore, not very surprisingly, snow is more important for those who participate in winter sport activities $(n=98)$; almost $85 \%$ of those doing winter sports consider snow very important. Only for $24 \%$ of those who do not do winter sports $(n=100)$ snow is very important or rather important for $11 \%$.

The guests were also asked whether they would come back to the Hochschwarzwald if there were a lack of snow (no winter sport activities possible). The respondents had to choose between the answer possibilities 'no, I would visit another region', 'yes, I would come back' and 'do not know'. Overall, about 69\% $(n=166)$ would return to the Hochschwarzwald even without snow. This positive response is even more common among those who do not do winter sports ( $n=84$, approx. $87 \%$ ), but even $50 \%$ of those doing winter sports $(n=82)$ would actually return to the Hochschwarzwald without sufficient snow for winter sport activities.

Another goal of the survey was to find out about guests' and locals' attitudes towards climate change and its consequences for the region's tourism. When asked whether climate change is having and will have impacts on winter tourism in the region Hochschwarzwald ('no', 'yes', 'do not know'), the majority of respondents $(n=195)$ (about $84 \%$ ) claimed that 
they believed that climate change would have an impact on winter tourism in the Hochschwarzwald (see figure 2). There are hardly any differences between respondents who participate in winter sport activities and those who do not. The differences are also minimal between locals and guests. According to the survey, fewer locals ( $n=21$, approx. $76 \%$ ) believe that climate change is having and will have on winter tourism than guests do $(n=174)$ (85\%).

Asked about the impacts of climate change $(n=127)$, more than $66 \%$ of the respondents named 'less snow', about 25\% named 'warmer temperatures' and about $17 \%$ 'negative effects on winter sport activities.

Offer analysis - sustainable alternatives for snow tourism

Hostels can improve sustainable accommodation supply in the Black Forest, particularly for young tourists and families. The evaluation of interviews with 16 hostel operators and web research about another six hostels in France, Germany, Belgium and Switzerland resulted into three typical models in lower mountain ranges, due to situation, visitors and their activities: sightseeing hostels (close to tourist points of interest like old towns, peaks, lakes,

\section{The importance of snow for the current stay in the Hochschwarzwald (\%)}

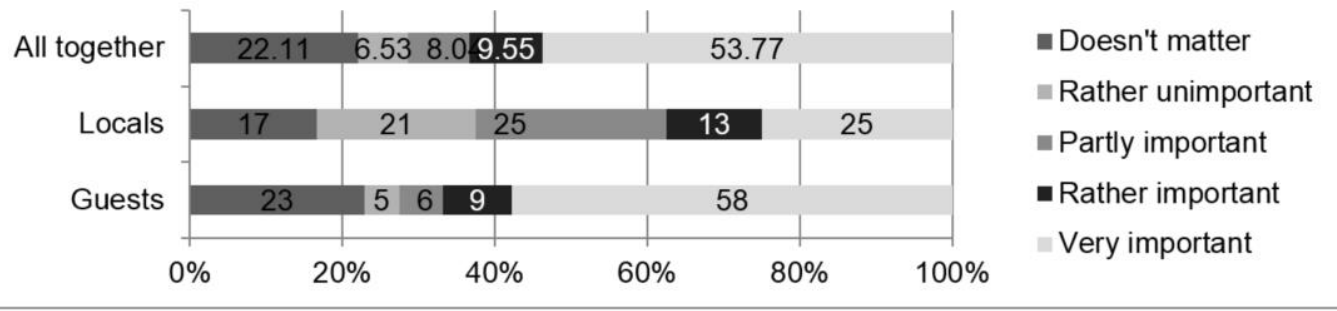

Figure 1 . How important is snow for your current stay in the Hochschwarzwald?

\section{Impacts of climate change on winter tourism in the Hochschwarzwald (\%)}

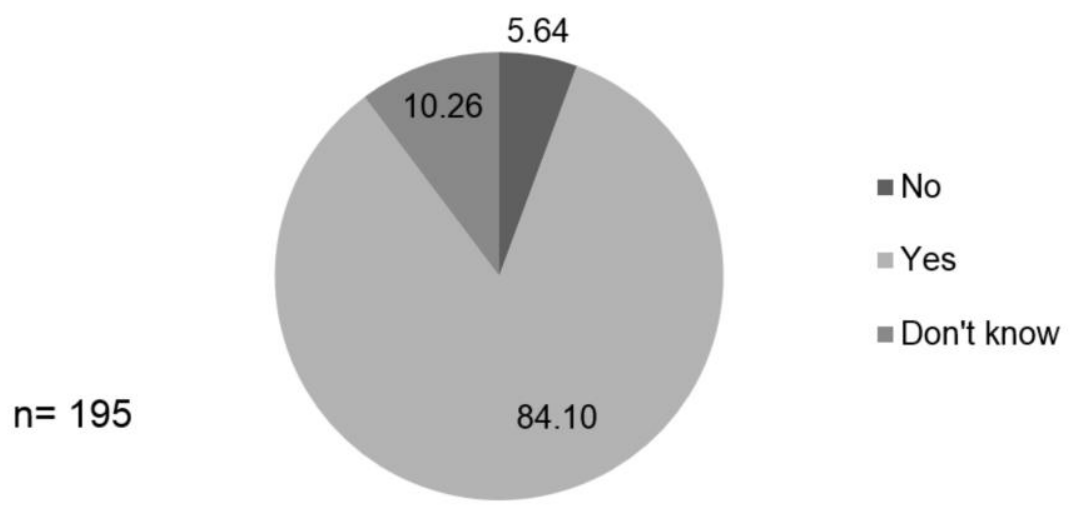

Figure 2 . Do you think that climate change is having and will have an impact on winter tourism in the Hochschwarzwald? 
canyons), sport hostels (close to skiing, climbing, biking, rafting, riding locations) and hiking hostels (situated in lower mountains, along rivers, lakes, or in small old towns). This typology developed from the accommodation type of gîte d'etape in French speaking areas in Europe can serve as a blueprint for the Black Forest, generating a year-round sustainable hostel offer.

\section{Discussion}

Considering the empirical findings of this research, it is surprising that climate change has not encouraged tourism stakeholders to act so far. Even though snow reliability is decreasing in low mountain ranges and people are aware of climate change effects, climate neutrality does not seem to lead to an adequate change in tourism behaviour. Climate change mostly appears to be a natural challenge for winter tourism. Although the sustainable business models like hostels exemplify how to broaden the offer of sustainable tourism experience and accommodation in the Black Forest, due to a wide range of factors in the Black Forest (altitude, traffic connections, population, tourism intensity, local climate etc.) it will not be easy to transfer this type of accommodation, especially in terms of profitability.

The analysis of the demand side shows how important snow is for winter tourism and recreational purposes. Still, the Black Forest appears to be an attractive destination for reasons other than just snow, since tourists intend to come back even in case of lack of snow. This may seem contradictory at first, but can be explained by the fact, that tourists are flexible in choosing alternatives to snow tourism and at the same time e. g. select other areas for snow tourism like the Alps that are rather close by. The strength of the Black Forest region seems to be the wide range of tourist offers and activities, which also may lead the destination through changes due to climate change and contribute to the compensation of the fading snow tourism possibilities in the long run. It is always problematic to speak of climate change adaption strategies since this implies, that the effects of climate change are manageable anyway. Indeed, climate change in the Black
Forest cannot be avoided any more, but mitigation is also relevant. In the Black Forest EMAS and VIABONO certification in a number of companies are indeed existing. But overall, the measures appear "too little and too late" in relation to the 2-degree target (Paris Agreement, UN 2015), or the federal governments aims $(-40 \%$ CO2 until 2020 , Bundesregierung 2010) or the regions' greenhouse gas reduction targets $(-25 \%$ by 2020 , $-50 \%$ by 2050 , Climate Protection Bill Baden-Württemberg from 2013; all reductions related to year 1990).

\section{Conclusion and Limitations}

Adressing the first research question, it can be concluded that climate change will affect the Black Forest as a low mountain range with reduced and vanishing winter sports offers. There are - referring to the second research question - occasional strategies for coping with climate change (strengthening public transport for guests, diversifying the tourism offer beyond skiing, sustainability schemes), but these cannot be seen as direct reactions on climate change, they follow more a general trend of sustainability. The effects of climate change regarding winter tourism are still too far away in time for tourism decision makers to take action. Whether the diversification of tourist offerings really reflects climate change adaption at all, or whether it is primarily based on general market strategies is difficult to determine unequivocally.

As to the third research question, snow is indeed an important factor in winter tourism, especially for tourists interested in winter sports, but also an emotional, atmospheric "winter wonderland", a white landscape as the background for other tourism activities in winter. However, since tourism numbers are rising in the Black Forrest even in winter, this may in future compensate for the loss of winter sports tourists in the long run anyway. Concluding with the fourth research question, new accommodation types that are sustainable, e. g. hostels, may be added as year-round post-snow era tourism offers.

Regarding limitations of this paper, the limited representativeness of all empirical work has to be taken into consideration. Among hostel 
operators only the ones capable of speaking English or German were willing to answer the interview questions; with regard to the tourism demand data, the sample size is quite small, Also, the spatial and temporal limitation needs to be taken into account, since the survey was only conducted in the southern parts of the Black Forest and only on three weekends.

\section{Aknowledgements}

The authors would like to thank two anonymous reviewers for their comments. The research was financed by Landesanstalt für Umwelt Baden-Württemberg (LUBW).

\section{References}

Abegg, B. (2012). Natürliche und technische Schneesicherheit in einer wärmeren Zukunft. Forum Wissen, 29-35.

Abegg, B., \& Elsasser, H. (1996). Klima, Wetter und Tourismus in den Schweizer Alpen. Geographische Rundschau, 48(12), 737742.

Bundesregierung (2010): Energiekonzept für eine umweltschonende, zuverlässige und bezahlbare Energieversorgung: Beschluss des Bundeskabinetts vom 28.September, 2010, Berlin. URL: https://www.bundes regierung.de/ContentArchiv/DE/Archiv17/ Anlagen/2012/02/energiekonzeptfinal.pdf;j sessionid=56B007D59A0DEE84C125FAD 2F8403145.s5t1? blob=publicationFile\& $\mathrm{V}=5$ ) (Accessed on 13.06.2018).

Doering, A., \& Hamberger, S. (2015). Der gekaufte Winter: Eine Bilanz der künstlichen Beschneiung in den Alpen. München.

Elsasser, H., Bürki, R., \& Abegg, B. (2000). Klimawandel und Schneesicherheit. Petermanns Geographische Mitteilungen, 144(4), 34-41.

Endler, C., \& Matzaraktis, A. (2011). Climatic potential for tourism in the Black Forest, Germany - winter season. International Journal Biometeorology, 55, 339-351.

Gebhard H., \& Höpker, K. (2015). Klimawandel in Baden-Württemberg. Fakten - Folgen Perspektiven. $3^{\text {rd }}$ Edition. Karlsruhe.

Gössling, S., Scott, D., Hall, C., Ceron, M., \& Dubois, G. (2012). Consumer behaviour and demand response of tourists to climate change. Annals of Tourism Research, 39(1), 36-58.
Gössling, S., Peeters, P., Ceron, J.-P, Dubois G., Patterson, T., \& Richardson, R.B. (2005). The eco-efficiency of tourism. Ecological Economics, (54), 417-34.

Gössling, S., Borgström Hansson, C., Horstmeier, O., \& Saggel, S. (2002). Ecological footprint analysis as a tool to assess tourism sustainability. Ecological Economics. 43(2/3), 199-211.

Hemberger, C., \& Utz, J. (2013). Anpassungsstrategie Baden-Württemberg an die Folgen des Klimawandels. Ministerium für Umwelt, Klima und Energiewirtschaft Baden-Württemberg; LUBW Landesanstalt für Umwelt, Messungen und Naturschutz BadenWürttemberg (ed.). Karlsruhe.

Hodeck, A., \& Hovemann, G. (2017). Bestimmungsfaktoren für die Destinationswahl im Wintersporttourismus deutscher Mittelgebirge. In: Roth, R. \&. Schwark, J. (eds.) (2017). Wirtschaftsfaktor Sporttourismus. Ressourcenmanagement, Produkt- und Destinationsentwicklung. Schriften zu Tourismus und Freizeit, 19, 159-165.

Jacob, R., Heinz, A., \& Décieux, J.-P. (2013). Einführung in die Methoden der Umfrageforschung. München.

LUBW Landesanstalt für Umwelt, Messungen und Naturschutz Baden-Württemberg (2017). Klimawandel in BadenWürttemberg: Anpassungen. Karlsruhe.

LUBW Landesanstalt für Umwelt, Messungen und Naturschutz Baden-Württemberg (2013). Zukünftige Klimaentwicklung in Baden-Württemberg. Perspektiven aus regionalen Klimamodellen. Karlsruhe.

Koesler, B. R. (2011). Klimawandel und Bewusstseinsbildung. Zur Berücksichtigung der Klimaanpassung in den Tourismusstrategien des Schwarzwalds und Nordhessens. Forschungsbericht BMBF-Projekt KLIMZUG. Kassel.

Kruse, J. (2014). Qualitative Interviewforschung: Ein integrativer Ansatz. Weinheim, Basel: Beltz Verlag.

Matzarakis, A., \& Lohmann, M. (2017). Tourismus. In Brasseur, G. P., Jacob, D. \&. Schuck-Zöller, S. (eds.) (2017). Klimawandel in Deutschland: Entwicklung, Folgen, Risiken und Perspektiven. Berlin, Heidelberg: SpringerOpen, 235-240. 
Ministerium für Umwelt, Klima und Energiewirtschaft Baden-Württemberg, \& LUBW Landesanstalt für Umwelt, Messungen und Naturschutz BadenWürttemberg (eds.) (2016). Klimawandel in Baden-Württemberg: Fakten - Folgen Perspektiven. Stuttgart.

Pröbstl-Haider, U., Mostegl, N., Jandl, R., Formayer; H., \& Haider, W. (2015). Understanding and directing small-scale private forest owner behaviour towards climate change adaptation. Our common future under climate change. Paris, France, July 7-10, 2015.

RADOST (2012). 3. RADOST Jahresbericht: April 2011-März 2012. Berlin. URL: https://www.ecologic.eu/sites/files /publication/2014/radost-jahresbericht-iii2012_1.pdf (Accessed on 13.06.2018).

Roth, R., Krämer, A., Kobernuß, J.-F., \& Schrahe, C. (2013). Anpassungsstrategie Baden-Württemberg an die Folgen des Klimawandels: Fachgutachten für das Handlungsfeld Tourismus. Stuttgart.

Roth, R., Prinz, N., \& Krämer, A. (2005). Nachhaltige Entwicklung des Schneesports und Wintersporttourismus in Baden-Württemberg. Ein Leitfaden für Politik, Sport, Kommunen und touristische Leistungsträger. Schriften des Wirtschaftsministeriums Stuttgart.
Schneider, C., Sauter, T., \& Weitzenkamp, B. (2009). Klimawandel und Wintersport in Mittelgebirgen. Nationalatlas aktuell 2009/11. URL: http://aktuell.nationalatlas. de/wp-content/uploads/09_11_Klimawan del.pdf (Accessed on 25.11.2017).

Schwarzwald Tourismus GmbH (n. y.). KONUS-Gästekarte: Mit Bus und Bahn den Schwarzwald gratis erleben. URL: http://www.schwarzwald-tourismus.info/ service/konus2 (Accessed on 13.06.18).

Statistisches Bundesamt (2011-2017). Binnenhandel, Gastgewerbe, Tourismus: Ergebnisse der Monatserhebung im Tourismus. Fachserie, 6 (71)

UGA Umweltgutachterausschuss (2017). EMAS-Register. URL: http://www.emasregister.de/recherche?regnr=DE-\&mana gementzentrale=on\&bundesland $=$ Baden W\%C3\%BCrttemberg\&naceCodes $=55$ \&erweitert=true (Accessed on 13.06.18).

UM - Ministerium für Umwelt, Klima und Energiewirtschaft Baden-Württemberg (ed.) (2017). Monitoring-Bericht zum Klimaschutzgesetz Baden-Württemberg. Teil I Klimafolgen und Anpassung. Stuttgart.

UN (2015). Paris Agreement. URL: https://unfccc.int/sites/default/files/english paris_agreement.pdf (Accessed on 13.06.2018). 